\title{
AL-KINDĪ AND THE MU'TAZILA: DIVINE ATTRIBUTES, CREATION AND FREEDOM
}

\author{
PETER ADAMSON
}

The 'Abbāsid caliphs al-Ma'mūn and al-Mu'tașim, who between them reigned from 198 to 227 A.H. (813-842 A.D.) are best-known to historians of philosophy for two things. First, they supported a massive translation project that had already begun in the previous century with al-Ma'mūn's grandfather, al-Manșūr. The result was that many of the most important works of Greek philosophy and science were rendered into Arabic. ${ }^{1}$ Second, they made into official state dogma the theological views of the $\mathrm{Mu}$ 'tazila, who as a result became the dominant school of ilm al-kalàm in the first half of the $3 \mathrm{rd} / 9$ th-century. Before their influence waned during the reign of al-Mutawakkil (died 247/861), the Mu'tazila saw their teaching on the createdness of the Qur'ān enforced in the infamous mihna, and $\mathrm{Mu}$ 'tazilism remained a vibrant force well into the next century. ${ }^{2}$ It is thus natural to ask how these two policies might have interacted with one another. What impact, if any, did Mu'tazilite ideas have on those who carried out the translation project, and what impact did the translations have on the $\mathrm{Mu}$ 'tazila?

\footnotetext{
${ }^{1}$ On the translation movement see D. Gutas, Greek Thought, Arabic Culture (London, 1998). Other useful studies include 'A. Badawì, La transmission de la philosophie grecque au monde arabe (Paris, 1968); C. D’Ancona, La Casa della Sapienza (Naples, 1996); G. Endress, "Die wissenschaftliche Literatur," in W. Fischer (ed.), Grundriß der arabischen Philologie, Bd. III, Supplement (Wiesbaden, 1992); F.E. Peters, Aristoteles Arabus (Leiden, 1968).

${ }_{2}^{2}$ The most useful single work on early Kalām, including early Mu'tazilism, is J. van Ess, Theologie und Gesellschaft im 2. und 3. Jahrhundert Hidschra, in six volumes (Berlin, 1991-1995). The fifth and sixth volumes contain German translations of many of the relevant reports of $\mathrm{Mu}$ 'tazilite views. Throughout the paper I will cite reports from the original Arabic, but supply a reference to van Ess when applicable, with the abbrevation VE followed by section and text number. On the $\mathrm{Mu}$ 'tazila generally, see H. Daiber, Das theologisch-philosophische System des Mu'ammar Ibn 'Abbād asSulamī, Beiruter Texte und Studien 19 (Beirut, 1975), which is wide-ranging despite its main focus on Mu'ammar; A.N. Nader, Le système philosophique des Mu'tazila (Beirut, 1956); H.A. Wolfson, The Philosophy of the Kalam (Cambridge, 1976); as well as numerous studies by R.M. Frank cited throughout in what follows.
} 
This paper addresses the first of these two questions, by

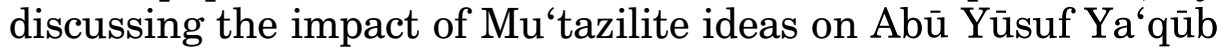
ibn Isḥāq al-Kindī (died soon after 256/870), whose circle of translators in Baghdad was responsible for Arabic versions of works by Plotinus, Proclus, and Aristotle, among others. ${ }^{3}$ It is well known that al-Kindi was deeply influenced by these translations, and that his extant treatises draw extensively on Aristotle, Neoplatonists (including commentators on Aristotle like John Philoponus), and other Greek authors ranging from Christian theologians to mathematicians like Euclid. Less obvious is the nature of his response, if any, to the $\mathrm{Mu}^{\text {'tazilite thinkers }}$ who held forth in Baghdad and Basra in his own day.

The issue was first raised by the editor of al-Kindì's works, Muhammad Abū Rìda, who argued in his preface to the edition that al-Kindi at the very least shared some theological concerns with the Mu'tazila. ${ }^{4}$ This was followed by Richard Walzer in his article "New studies on al-Kindi," 5 who also saw a strong connection between al-Kindi and the Mu'tazila, on the basis of a passage in which al-Kindī engages in Qur'ānic exegesis as a digression from itemizing the works of Aristotle (the passage will be discussed below, section II). Jean Jolivet provided a more wideranging comparison between al-Kindī and $\mathrm{Mu}$ 'tazilite authors in his L'intellect selon Kindī, concluding that al-Kindì was "the most theological of the philosophers of Islam, and the most philosophical of the Mu'tazilites." "6 These studies paved the way for Alfred Ivry's discussion in his translation of al-Kindì's On First Philosophy. ${ }^{7}$ Ivry's balanced and thoughtful piece yields the conclusion that al-Kindi was aware of and responding to the $\mathrm{Mu}$ 'tazila, but that he saw them chiefly as intellectual rivals. Particularly important in establishing this is Ivry's interpretation of a passage in On First Philosophy as a polemic aimed at the Mu'tazila. ${ }^{8}$

\footnotetext{
${ }^{3}$ See G. Endress, "The circle of al-Kindī," in G. Endress and R. Kruk (eds.), The Ancient Tradition in Christian and Islamic Hellenism (Leiden, 1997), pp. 43-76.

${ }^{4} \mathrm{Al}-K i n d \overline{1}$, Rasā'il al-Kindī al-falsafiyya, edited by M.'A.H. Abū Rīda, vols. 1-2 (Cairo, 1950, 1953), pp. 28-31.

${ }^{5}$ In R. Walzer, Greek into Arabic (Oxford, 1962), pp. 175-205.

${ }^{6}$ J. Jolivet, L'intellect selon Kindī (Leiden, 1971), p. 156.

7 "Al-Kindi and the Mu'tazilah: a reevaluation," in Al-Kindi's Metaphysics (Albany, 1974), pp. 22-34. Ivry's treatment begins with a useful summary of Walzer's and Abù Rìda's interpretations.

${ }^{8}$ Ivry's view finds favor with $\mathrm{H}$. Wiesener in The Cosmology of al-Kindi (unpublished Ph.D. thesis, Harvard University, 1993), p. 30: seeing the Mu'tazila as "rivals," al-Kindī
} 
Al-Kindi's relationship to the Mu'tazila is not, then, unfurrowed ground, and it is worth saying why I think it fruitful to revisit the issue here. First, there can be little doubt that al-Kindi was aware of and reacting to the Mu'tazila. That he was aware of them is simply obvious, given their prominence in his day many of his surviving works are dedicated to caliph al-Mu'tașim or his son, Ahmad, and thus date from between 218-227/833-842, when the mihna was in full swing. That he was reacting to them is most evident from the titles of some of his works that are, unhappily, lost to us. The list of al-Kindi's works in the Fihrist includes several that without doubt waded into controversies in which the $\mathrm{Mu}^{6}$ tazila were embroiled, ${ }^{9}$ including one that rejected the theory of atomism held by the majority of the Mu'tazila. ${ }^{10}$ Several others can be counted as probable engagements with the $\mathrm{Mu}$ 'tazila as well. ${ }^{11}$ Since these explicit reactions to the $\mathrm{Mu}$ 'tazila are lost, we must hope that further scrutiny of his extant works will yield signs of his engagement with them.

"acknowledged the differences in method and overlapping of subject matter between philosophy and Mu'tazilite kalām, and he took the side of philosophy." I.R. Netton, in "Al-Kindì: the watcher at the gate," in Allāh Transcendent: Studies in the Structure and Semiotics of Islamic Philosophy, Theology and Cosmology (London, 1989), pp. 4598, also takes a middle view, adding to the debate by pointing out that al-Kindi's understanding of God's oneness (tawhìd) looks Mu'tazilite in inspiration. On this see below, section I.

${ }^{9} \mathrm{~F} \overline{\mathrm{l}}$ anna af'āl al-bāri' kulluhà 'adl lā jawr fihā (On the fact that the acts of the creator are all just, and have no injustice in them), K. fi bahth qawl al-mudda'i anna al-ashyā' al-tabì 'iyya taf'alu fi 'lan wähidan bi-ījāb al-khilqa (Examination of the statement claiming that natural things perform only one act by the necessity of [their] innate nature [or creation]), and $R$. fi anna al-jism fi awwal ibdā ihi lā sākin wa lā mutaharrik zann bātil (On that it is a false opinion that the body is neither at rest nor in motion in the first moment of its creation). See Ibn al-Nadim, al-Fihrist, edited by G. Flügel (Leipzig, 1871-2), pp. 256.4, 8-9, and 259.18-19 for these three titles. Ahmad Hasnawi has pointed out that another title indicates that al-Kindi responded to a claim made by Abū al-Hudhayl: Fì al-radd 'alā man za'ama anna li-al-ajrām fì huwiyyihā fi al-jaww tawaqqufät (On the refutation of those who claim that there are moments of rest in the falling of bodies through the air), in Ibn al-Nadim, al-Fihrist, p. 259.1617. See Hasnawi's entry on al-Kindī in L'encyclopédie philosophique universelle, general editor A. Jacob, vol. III: Les œuvres philosophiques, volume edited by J. F. Mattéi (Paris, 1992), pp. 655-7.

${ }^{10}$ R. fi buṭlān qawl man za 'ama anna juz' là yatajazzā' (On the falsity of the statement of one who alleges that there is an indivisible part): Ibn al-Nadim, al-Fihrist, p. 259.1920. This was mentioned previously by Ivry, Al-Kindi's Metaphysics, p. 50, footnote 52, and F. Klein-Franke in "Al-Kindī", History of Islamic Philosophy (London, 1996), 169.

${ }^{11}$ For example R. fi al-istițá 'a wa zamān kawnihā (On ability and the time of its generation): Ibn al-Nadim, al-Fihrist, p. 259.16. The Mu'tazilites Hafs al-Fard and $\mathrm{Mu}$ 'ammar ibn 'Abbād both wrote works by the title $F \bar{\imath}$ al-istiț̄a' $a$ : see van Ess, Theologie und Gesellschaft, vol. V, pp. 252 and 254. 
A second reason for returning to this question is that previous scholars have focused on al-Kindi's attitude towards Mu'tazilite methodology, rather than his attitude towards specific Mu'tazilite doctrines. One might think for instance of Walzer's discussion of al-Kindī's interpretation of the Qur'ān, or Ivry's point that alKindī was championing Greek rationalism - despite its foreign provenance - over the theological approach of the mutakallimün. The benefits of this strategy are clear enough. It helps to situate al-Kindī in the tradition of those who, like al-Fārābì and Ibn Rushd, would defend falsafa as an equal and even superior tradition to kalām. But what I will undertake here is a rather different project. Instead of focusing on the question of methodology, my contrast between al-Kindī and the $\mathrm{Mu}$ 'tazila will be based on three specific philosophical issues. These three issues, chosen because of their salience for the $\mathrm{Mu}^{\text {'tazila rather }}$ than their prominence in al-Kindì's extant works, are (1) divine attributes, (2) the nature of God's creative act, and (3) human freedom.

Of these al-Kindì's views on (1) divine attributes have received the most attention in the past, ${ }^{12}$ because he does deal with it prominently at the end of his most important work, On First Philosophy. In the case of (2) creation and (3) freedom, we will have to delve a bit deeper into al-Kindī's writings to find evidence about how he may have been reacting to the Mu'tazila. I will show that al-Kindi's ambivalent attitude toward $\mathrm{Mu}$ 'tazilite methodology is reflected in his treatment of $\mathrm{Mu}$ 'tazilite doctrines. $\mathrm{He}$ typically accepts these doctrines in their broad outlines, but transforms them by expounding and defending them in the context of falsafa rather than of 'ilm al-kaläm. Indeed, I hope to show that al-Kindi was deliberately taking on debates from within kalàm in order to show that philosophy has the resources to settle those debates. A particularly striking example of this will be provided in section II, where I show that al-Kindī was drawing directly on John Philoponus in order to reach a satisfactory interpretation of the Qur'àn's description of God's act of creating.

${ }^{12}$ M. Marmura and J. Rist, "Al-Kindī's discussion of divine existence and oneness," Mediaeval Studies, 25 (1963): 338-54; C. D’Ancona Costa, "Aristotele e Plotino nella dottrina di al-Kindī sul primo principio," Documenti e Studi Sulla Tradizione Filosofica Medievale, 3 (1992): 363-422; J. Janssens, "Al-Kindi’'s concept of God," Ultimate Reality and Meaning, 17 (1994): 4-16. 


\section{DIVINE ATTRIBUTES}

The most conspicuous point of contact between al-Kindì's

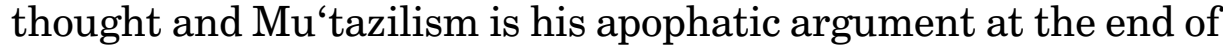
the surviving portion of On First Philosophy (Fì al-falsafa al- $\bar{u} l \bar{a}$, hereafter $F P$ ), which aims at showing that God cannot be spoken of in the way created things are spoken of. In fact his argument for this spans the whole second half of $F P,{ }^{13}$ beginning in chapter 3 with a classification of the types of utterance (malfüz: 126.8-10 [RJ 45.11-12]). ${ }^{14}$ This is followed by proofs that all things (other than God) are characterized by both unity and multiplicity. There must be a cause for this association of unity and multiplicity, a cause that is itself essentially one (132.10-13 [RJ 53.12-15]). In chapter 4 al-Kindi goes on to show that this cause, which he calls "the true One" (or "essentially One": al-wāhid bi-al-haqīqa), is not subject to any of the categories (maqülät), since these all imply multiplicity (153.9-12 [RJ 83.15-18]). The upshot seems to be that God, "the true One," is completely transcendent, in the precise sense that nothing can be said of Him. Al-Kindi does not use the term sifät, "attributes," for what would be said of God, but in other respects he seems here to follow the Mu'tazila in rejecting the application of normal discourse to God. ${ }^{15}$ Indeed, several scholars have previously remarked on this agreement between al-Kindì and the $\mathrm{Mu}$ 'tazila. ${ }^{16}$

${ }_{13}$ The entire argument has been summarized by Marmura and Rist, "Al-Kindī's discussion of divine existence," pp. 339-46.

${ }^{14}$ Citations to works of al-Kindī refer to page and line number from the edition of Abū Rīda: al-Kindī, Rasā'il al-Kindī al-falsafiyya; see above, footnote 4. All references are to volume I unless otherwise noted. Improved editions, with French translations, are now appearing in the series Euvres philosophiques et scientifiques d'al-Kindī, edited by J. Jolivet and R. Rashed. Some of the texts from which I will cite have already appeared in volume II of the series, Métaphysique et cosmologie (Leiden, 1998). Where applicable I will also cite page and line number from the editions in this volume, prefaced by the abbreviation RJ.

${ }_{15}$ Several texts produced under al-Kindì's guidance do however use the term șifät, including the Theology of Aristotle, the Book on the Pure Good (later known as the Liber de Causis), and the Opinions of the Philosophers of Pseudo-Ammonius. For the Theology see my The Arabic Plotinus: a Philosophical Study of the "Theology of Aristotle" (London, 2002), and on șifät see especially 5.4.4. For the de Causis see C. D'Ancona Costa, Recherches sur le Liber de Causis, Études de philosophie médiévale, vol. 72 (Paris, 1995). For Opinions of the Philosophers see U. Rudolph, Die Doxographie des PseudoAmmonios: ein Beitrag zur neuplatonischen Überlieferung im Islam (Stuttgart, 1989).

${ }^{16}$ See e.g. Daiber, Das theologisch-philosophische System des Mu'ammar, p. 134; Netton, "Al-Kindī: the watcher at the gate," pp. 57-8; Janssens, "Al-Kindī's concept of God," p. 14. 
Al-Kindi first establishes the existence of God via an analysis of the types of utterance. He itemizes them as "genus, form, individual, difference, and accident, peculiar [accident] or common accident," but then goes on to explain that in fact all of these subdivisions fall under two main classes: the substantial and the accidental (jawhariyya, 'aradiyya: 126.12 [RJ 45.14-15]). This distinction between the substantial or "essential" and the accidental is crucial to al-Kindî's first, brief argument for the existence of God:

Whatever is in one thing in an accidental way is in something else in an essential way $(d h \bar{a} t \bar{l})$, for whatever is in one thing accidentally is in another essentially (bi-al-dhāt). And since we have made it clear that unity is in all these [i.e. created things] accidentally... the unity that is in [them] accidentally is acquired from what has unity in it essentially. Therefore, here is necessarily a true One, uncaused in unity. (132.8-14 [RJ 53.10-15])

I will return below to the assertion, which must strike us as odd in the midst of al-Kindi's apophatic argument, that God may after all be called "one," but "essentially" or "through Himself" (both of which are possible translations of bi-al-dhàt).

First, let us compare the theory of utterance used in al-Kindī's argument to that espoused by the $\mathrm{Mu}$ 'tazila. Generalizations about $\mathrm{Mu}$ 'tazilite doctrines must be made with caution, since even restricting our attention to those who worked before or during al-Kindī's time, there is a wide array of various views held by thinkers associated with the $\mathrm{Mu}$ 'tazilite tradition. ${ }^{17}$ Still, the rough outlines of a shared theory of language emerge from later reports of their doctrines. This theory was put forward primarily in the service of a negative theology that originated with the putative founder of Mu'tazilism, Wāșil ibn 'Ațā'. According to alShahrastānī, Wāșil argued that to posit an eternal divine attribute would be to assert the existence of a second God. ${ }^{18}$ Later

\footnotetext{
${ }^{17}$ Indeed, it would be anachronistic to suppose that al-Kindī himself would already see all the figures I will mention shortly, in both the Baghdadian and Basrian traditions, as a monolithic "school" called the Mu'tazila, defined by certain shared doctrines. It is reasonable to suppose that he was aware of a tendency among numerous of his contemporaries towards embracing negative theology or the reality of human freedom, for example, and that he was aware that these figures formed a distinctive group or groups. But my argument does not require even this fairly modest historical assumption; it is sufficient for my purposes that al-Kindi was aware of and responding to the doctrines of particular theologians (such as, and I suspect especially, Abū alHudhayl) that the later tradition classified as $\mathrm{Mu}^{\text {'tazilite. }}$

${ }^{18}$ Al-Shahrastānī, Kitāb al-Milal wa al-nihhal, edited by 'A. al-Wakìl in two volumes (Cairo, 1968), p. 46.12-13. See further Nader, Le système philosophique des Mu'tazila, pp. 49-50.
} 
Mu'tazilites agreed, often providing additional arguments for the point, that God's oneness prevents our positing real and distinct divine attributes. So far, this seems not unlike what we find in al-Kindì.

But what do the $\mathrm{Mu}$ 'tazila mean when they say that there are no such divine attributes? Later, hostile authors like alShahrastānī are quick to accuse the Mu'tazila of $t a$ 'țill, the rejection of the attributes authorized by the Qur'ān. A more sympathetic interpretation must recognize that they do have a positive theory of divine discourse. But to see this we must begin from their theory of non-divine discourse: the "attributes" of things God has created. According to most of the Mu'tazilites, created things consist of atoms, which are the bearers for attributes. These attributes are called "accidents" $(a$ ' $r \bar{a} d) .{ }^{19}$ Here is a typical report of their views from our most reliable source of information on the early Mu'tazila, al-Ash'arī:

Some, among them Abū al-Hudhayl, Hishām, Bishr ibn al-Mu'tamir, Ja'far ibn Harb, Iskāfi, and others, said that motions and rests, standing and sitting, combinations and separations, length and breadth, colors, tastes, odors, and sounds, speaking and silence, obedience and disobedience, unbelief and professions of belief, and other acts of man, as well as heat and cold, moisture and dryness, and softness and roughness, are accidents, not bodies. ${ }^{20}$

Now, there is a considerable degree of variation within the physical theories of the early Mu'tazila. Abū al-Hudhayl, for example, holds that a few accidents, such as rest and motion, are predicated directly of atoms, while most supervene on collections of atoms, which he calls "bodies." 21 Dirār ibn "Amr on the other hand says that there are no atoms, and that bodies are rather collections of accidents without any distinct bearer for the accidents apart from the body that is constituted from those

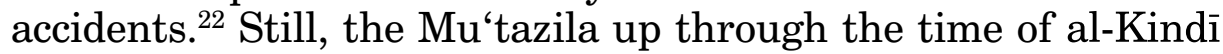
seem by and large to agree on the following two principles:

${ }^{19}$ Sometimes the word $m a^{\prime} \bar{a} n \bar{\imath}$ is used instead, but without suggesting that the properties are essential. See R.M. Frank, "Al-ma'nà: Some reflections on the technical meaning of the term in the Kalām and its use in the physics of Mu'ammar," Journal of the American Oriental Society, 87 (1967): 248-59, at p. 249.

${ }^{20} \mathrm{Al}$-Ash'arī, Maqālāt al-islāmiyyīn wa ikhtilāf al-muṣallīn, edited by H. Ritter, Bibliotheca Islamica 1a-b (1929), 345.6ff [VE XVII.13].

${ }^{21}$ Ibid., 311.11-312.1 [VE XXI.4].

${ }^{22}$ Ibid., 305.5-7 [VE XV.1]. On Dirār see J. van Ess, "Dirār b. 'Amr und die 'Cahmiyya': Biographie einer vergessenen Schule,” Der Islam, 43 (1967): 241-79, and 44 (1968): 1-70. 
(a) Whatever inheres in something else is a created attribute, or "accident."

(b) Such attributes are distinct from one another and from that in which they inhere (which is usually taken to be an atom or collection of atoms).

Here I want to draw attention to the fact that, unlike al-Kindi, the $\mathrm{Mu}$ 'tazila typically recognize only one type of properties or inhering features in the case of created things, namely what they call accidents. That is, they do not have anything like the Peripatetic distinction between the "essential" and "accidental" properties of created things (which means of course that the Mu'tazilite notion of "accident" does not correspond exactly to the Peripatetic one). ${ }^{23}$ Thus Richard Frank has written that for Abù al-Hudhayl, "the beings that we most readily identify as such - a man, for instance, an animal or the like - have not any essential unity of being beyond the material unity of the body... its being is that of a composite, a specific arrangement of atoms conjoined and juxtaposed in space together with a complex set of accidents which inhere in them, not 'by nature' as essential properties belonging to its being, but simply as created in them."24

What position would the Mu'tazila have to take on divine attributes, if principle (b) also held true for theological discourse? It would follow from this principle that divine attributes would be a plurality of things that are distinct from one another and from God. But as already mentioned, from Wāșil onwards this position is taken to compromise tawhid, and to represent polytheism, because it posits a number of things that are co-eternal with God. This makes sense of what the Mu'tazila say when they do turn to the question of divine discourse. For in fact they seek, in a variety of ways, to safeguard the truth of statements such as "God is knowing" and "God is powerful." But they typically do

\footnotetext{
${ }^{23}$ While one might make an exception in the case of $\mathrm{Mu}$ 'ammar, he seems to me an exception that proves the rule. He distinguishes between the properties of a thing, which he calls $m a$ ' $\bar{a} n \bar{\imath}$, and the "nature" $\left(t a b^{\circ}\right)$ of the thing, which might be thought to constitute a division between accidents and essence (see the critique of Wolfson's comparison of Mu'ammar's view to Aristotle in Frank, "Al-ma'nà"). But in fact the "nature" does not constitute a separate class of attributes or properties: rather it is the cause or source of those properties. See al-Khayyāt, Kitāb al-Intișār, edited by A. Nader (Beirut, 1957), p. 45.22-24: "Know that Mu'ammar maintained that the forms (hay'āt) of bodies are a natural act $\left(f^{\prime} l\right)$ from the bodies, in the sense that God formed them in such a way that they would naturally make (taf'alu) their forms."

${ }^{24}$ R.M. Frank, "The divine attributes according to the teaching of Abū 'l-Hudhayl al-‘Allāf," Le Muséon: Revue des études orientales, 82 (1969): 451-506, at p. 464.
} 
so by showing how we can avoid accepting principle (b) in the case of God. For instance, Abū al-Hudhayl affirms both that God's attributes are the same as Him (al-sifāt... hiya al-bāri'), ${ }^{25}$ and that His attributes are not distinct from one another. ${ }^{26} \mathrm{Abu}$ alHudhayl and other Mu'tazilites also suggest that, unlike created things, God may have attributes by virtue of His "essence" (dhàt). ${ }^{27}$ But the Mu'tazila cannot defend this claim by appealing to an analogy between God's attributes and the essential properties in created things, because by principle (a), they do not believe that created things have essential properties.

Now, al-Kindi agrees with the claim that nothing can be coeternal with God without compromising His oneness. Indeed I believe this is the unifying theme of FP: it explains the seemingly fortuitous juxtaposition of the argument against the eternity of the world in chapter 2 with the argument for God as the true One in chapters 3-4.28 To hold that the world is co-eternal with God is to violate tawhid. But his analysis of statements about God's effects is significantly different from that of the $\mathrm{Mu}^{\text {'tazila, and }}$ this leads to a correspondingly different position on divine attributes. Indeed I hope that the contrast with the Mu'tazila may help to bring out positive aspects of al-Kindi's theology, aspects that have not previously been noticed because of the prominence of his negative theology.

As we saw, al-Kindi does distinguish between the essential and accidental features of sensible things. He also uses this distinction to explain the distinctive unity that is found only in God, by repeatedly asserting that created things have unity "accidentally" or from an extrinsic cause, while God has unity essentially (bi-aldhāt: FP 161.2 [RJ 95.16]). What does al-Kindì mean here by

${ }^{25}$ Al-Ash'arì, Maqālāt al-islāmiyyīn, 177.14-15 [VE XXI.62].

${ }^{26}$ Ibid., 177.15-16 [VE XXI.62]: "If someone asked [Abū al-Hudhayl]: 'is [God's] knowledge [God's] power?' He said, 'it is false to say that it is [His] power, and false to say that it is other than [His] power."' See also 484.15-485.6 [VE XXI.64].

${ }^{27}$ For this position in al-Nazzām see al-Ash'arī, Maqālāt al-islāmiyyīn, 486.10-14 [VE XXII.173]. For 'Abbād ibn Sulaymān, see 165.14ff [VE XXV.27], and also Daiber, Das theologisch-philosophische System des Mu'ammar, pp. 203ff. Similarly Dirār says that God is "knowing" and so on "through Himself" (li-nafsihi): al-Ash'arī, Maqālàt al-islāmiyyīn, 281.14 .

${ }^{28}$ The two themes are joined also in his short treatise On the Oneness of God and the Finitude of the Body of the World (Fì wahdāniyyat Allāh wa tanāhì jirm al- ‘àlam), 201207 [RJ 137-147]. Here it is relevant to note that Ibn Hazm seems to have known FP under the title Kitāb al-tawhìd: see H. Daiber, "Die Kritik des Ibn Hazm an Kindīs Metaphysik," Der Islam, 63 (1986): 284-302, at p. 287 note 29. 
"essentially"? Usually al-Kindī defines essential properties as follows: a thing is essentially $\mathrm{F}$ if it would be destroyed by becoming not-F. Thus humans are essentially alive and rational; if they were to become non-living or non-rational their substance would be corrupted..$^{29}$ But if this is what he means by "essential" in this context it seems absurd to claim that only God is "essentially" one. After all, I am one human; if I cease to be one then the substance that I am will be destroyed. And in fact, the text makes it clear that al-Kindi accepts this sort of essential unity in the case of created things:

"One" is said either essentially or accidentally (immā bi-al-dhāti wa immā bi$a l$-'aradi $i$. Accidentally, it may be predicated homonymously or synonymously, or [by virtue of] a collecting of multiple attributes, as when we say that the writer and the speaker are one, since they are both said of a single man, or of man [generally]... The essentially [one] is whatever else is called "one," among the things we have mentioned that are called "one" - namely, all that whose substance is one (jawharuhā wāhidun). (159.3-7 [RJ 93.4-9])

What, then, is the difference between the created thing whose substance is one, and is thus essentially one, and God, Who is essentially one? Al-Kindì answers this question in what follows, as he points out that although the created substance is essentially one in substance, it is multiple in other respects: by having material parts, for example. God, by contrast, is not multiple in any way:

Unity is an accident in all things other than the true One, as we have said. But the true One is one essentially, not being multiple in any way at all, and being undivided by species, or by virtue of its essence, or by virtue of anything else, or by time, place, subject, predicate, whole, or part, from substance or from accident, or any other kind of division or multiplicity at all. (160.17-161.5 [RJ 95.15-19])

What is distinctive about God, then, is not so much that He is one by His very nature, but that $\mathrm{He}$ is one by His very nature and not multiple in any respect.

This seems to be what al-Kindī means when he says that God is one "essentially" instead of "accidentally," and also when he says that God is one "in truth" (bi-al-haqiqa) while created things are one only "metaphorically" (bi-al-majāz) (FP 143.12 [RJ 69.4]; 161.11 [RJ 95.26]). One might be tempted to say that this emphasis

${ }^{29}$ For this conception of essential properties in al-Kindī see e.g. FP 125.4-7 [RJ 43. 15-19]. 
on God's unity does not count as accepting the reality of a divine attribute: it could be objected that "oneness" in this absolute sense is nothing more than not having a multiplicity of attributes. But al-Kindi means more than this when he speaks of God's oneness, for he goes on to claim that God is the principle and source of unity for created things (FP 161.10-14 [RJ 95.24-96.3]). Thus oneness is something positive, so much so that al-Kindi is willing to describe God's creative act as an emanation of oneness onto sensible things (FP 162.2-3 [RJ 97.8-9]).

Furthermore, the argument we have seen is repeated for another divine attribute elsewhere. God's being only F, rather than both $\mathrm{F}$ and not-F, also dominates the much shorter treatise entitled On the True, First, Complete Agent and the Deficient Agent that is [an Agent] Metaphorically. ${ }^{30}$ Here al-Kindi does not use the distinction between essential and accidental at all. Instead he distinguishes God from created things, by saying that God is the "true Agent" (al-fä il al-haqq), while His effects are agents only in a metaphorical sense. This is because God alone acts without being acted upon (183.6 [RJ 169.10-11]), whereas created things are acted upon and indeed only "act" in the sense that they pass on an extrinsic act to other things (see below, section (III), for further discussion of this distinction). Just as, in his discussion of divine oneness in FP, al-Kindi insisted that God is one and in no respect multiple, here he insists that God is truly an agent, and the only true agent, because only God is acting and not at all passive or acted upon.

Again, the force of "metaphorically" here does not seem to be that God is an agent in a quite different sense from created agents: we are not in the presence of a theory of analogy, such that the same term is applied with two different modes or meanings. ${ }^{31}$ Rather, what al-Kindi means is that something is "metaphorically" F just in case it is $\mathrm{F}$ in one respect and not-F in another respect. If we were to expand this doctrine and apply it to all divine attributes, we would have the following theory: for any divine attribute F, God is truly $\mathrm{F}$ because He is essentially $\mathrm{F}$

\footnotetext{
${ }^{30}$ Al-fā'il al-haqq al-awwal al-tāmm wa al-fā'il al-nāqiṣ alladhì huwa bi-al-majāz, 182-184 [RJ 169-171].

${ }^{31}$ Notice, however, that just as in a theory of analogy such as that of Aquinas, it is God as the first cause Who is the primary referent of divine predicates, so here God is the agent or "one" in truth, while created things are metaphorically one and agents.
} 
and in no respect not-F. ${ }^{32} \mathrm{Al}-\mathrm{Kindi}$ does not try thoroughly to apply this principle to all divine attributes, but he explicitly accepts it in the case of the attributes "one" and "agent." 33

Al-Kindī's argument engages with a Mu'tazilite problematic, and does what the $\mathrm{Mu}$ 'tazila typically sought to do: reject any theory of divine discourse that would require a plurality of attributes co-eternal with God, while nevertheless affirming the truth of the statement that "God is one," for instance. His

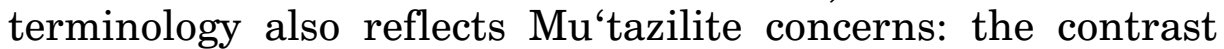
between the metaphorical and non-metaphorical use of words, which grows out of the study of Arabic grammar that inspired so much of $\mathrm{Mu}^{6}$ tazilite theology, was used for similar purposes by the Mu'tazila and other mutakallimūn. Mu'ammar ibn 'Abbād al-Sulami is said to have held that God has a word "not in truth ( $f i$ al-haqiyya) but only metaphorically ('alā al-majāz),"34 and the same contrast was used by the early theologian Jahm ibn Safwān. ${ }^{35}$ In part al-Kindī's solution to the problem of divine attributes agrees with the $\mathrm{Mu}$ 'tazila, by associating the attributes with God's "self" or "essence" (dhāt). But he reaches this result on the basis of an analysis of non-divine predication that owes a great deal to Aristotle and Porphyry's Isagoge. He also leaves

\footnotetext{
${ }^{32}$ This argument is similar to Plato's argument for the Forms, which are supposed to exclude their contraries, unlike the sensible particulars that participate in the Forms. Interestingly al-Kindi's view seems to reverse what we find in texts produced in his own circle of translators: the Theology of Aristotle seeks to guarantee divine transcendence by asserting that God, rather than creatures, is both F and not-F. See my The Arabic Plotinus, chapter 5.

${ }^{33}$ Why these two attributes? While any answer would be speculative, it is striking that the two attributes seem to stem from the two philosophical traditions that most influenced al-Kindì: he has from Neoplatonism (especially the Theology) the claim that God is one, and from Aristotle (as interpreted by Ammonius) the idea that God is an efficient cause. But Aristotle could also be a source for the oneness of God: in Metaphysics XII.10 he presents the Prime Mover as both one and the cause of the unity of all things.

${ }^{34}$ Daiber, Das theologisch-philosophische System des Mu'ammar, p. 171. Cf. W. Heinrichs, "On the genesis of the Haqũqa-Majāz dichotomy," Studia Islamica, 59 (1984): 111-40.

${ }^{35} \mathrm{Jahm}$ may even have been a source for al-Kindi's On the True Agent, because he too held that God alone acts " fi al-haqiqqa," while humans only act "alä al-majāz" (AlAsh'arī, Maqālāt al-islāmiyyīn, 279.3-5 [VE XIV.6]). The parallel was already noticed by Daiber, Das theologisch-philosophische System des Mu'ammar, p. 375, footnote 5. Note however that Jahm, who rejected human freedom, used the contrast to suggest that humans are no more agents than the sun when it sets, while al-Kindi means something quite different by saying that created things are metaphorically agents. Indeed, as we will see, al-Kindī agrees with the $\mathrm{Mu}$ 'tazila, not Jahm, in ascribing freedom to human agents.
} 
room for Aristotelian essential properties in the case of created things, and builds on this to explain divine discourse. But to safeguard the uniqueness of such discourse, he needs to stipulate that God alone possesses attributes in such a way as completely to rule out their contraries. This treatment of divine attributes shows al-Kindì responding to the $\mathrm{Mu}$ 'tazila and even agreeing with them in spirit. Yet it also shows him giving arguments based on the tradition of falsafa rather than kalàm, and expanding on that tradition with a theory of his own devising.

\section{CREATION}

One of the obstacles to our understanding of the $\mathrm{Mu}$ 'tazila is the fact that they devoted so much of their energy to theological disputes that may seem to us impossibly recondite and technical. A prime example is their debate over whether the "non-existent ( $m a$ 'd $\bar{u} m$ )" is a "thing (shay')." 36 The question seems to have been first formulated explicitly by Abū Ya'qūb al-Shaḥhām, a disciple of Abù al-Hudhayl. Al-Shaḥhām said that the non-existent is indeed a thing. ${ }^{37}$ To understand what he meant by this we need to consider the status of the things God creates, prior to His creating them. Insofar as these things have not yet been created, they are "non-existent." Yet one might think that God knows things about them even before He creates them: the fact that He will create them, for example. This suggests that, before things are created, they are already things, for they are objects of God's knowledge, and an object of knowledge must be a thing. ${ }^{38}$ Arguing against the view of the early theologian Hishām ibn al-Hakam, ${ }^{39}$

\footnotetext{
${ }^{36}$ For general discussion of the issue see J. van Ess, Die Erkenntnislehre des 'Adudaddīn al-İcī (Wiesbaden, 1966), pp. 191ff; R.M. Frank, "Remarks on the early development of the Kalam," Atti del Terzo Congresso di Studi Arabi e Islamici (Napoli, 1967), pp. 315-29, especially at pp. 324-5; R.M. Frank, "Al-Ma'dūm wal-Mawjūd: the non-existent, the existent, and the possible in the teaching of Abū Hāshim and his followers," MIDEO, 14 (1980): 185-209; F. Klein-Franke, "The non-existent is a thing," Le Muséon, 107 (1994): 375-90. On the related discussion of "thingness" and the relation between shay' and wujūd in Avicenna, see T.-A. Druart, "Shay' or Res as concomitant of 'being' in Avicenna," Documenti e Studi sulla Tradizione Filosofica Medievale, 12 (2001): 125-42, and R. Wisnovsky, "Notes on Avicenna's concept of thingness (shay'iyya)," Arabic Sciences and Philosophy, 10 (2000): 181-221.

${ }^{37}$ Al-Ash'arī, Maqūlāt al-islāmiyyīn, 505.1-2 [VE XXVI.1]. Cf. VE XXVI.3.

${ }^{38}$ Ibid., 162.8-12 [VE XXVI.2].

${ }^{39}$ Ibid., 37.8-10; 493.15-494.1 [VE IV.39].
} 
Abū al-Hudhayl had already staked out the Mu'tazilite view on this issue by insisting that God does indeed know things before He creates them. He even added that those things must have a "limit (nihàya)," because God knows that He will create a finite world. ${ }^{40}$ But he did not, so far as we know, develop this into the explicit claim that the non-existent is a thing. Still, in making that claim al-Shaḥām seems merely to have been drawing the logical consequence of Abù al-Hudhayl's argument.

Another way of putting the point, emphasized by Richard Frank, ${ }^{41}$ is to say that before something exists it is still possible, and that the possible is something, not nothing. In this case the argument proceeds from God's prior power, rather than His prior knowledge. God's creating something is His actualizing its possibility for existing. This suggests that, if God is eternally able to create something, then there is an eternal possibility for that thing. One can make this claim without saying, in contemporary parlance, that creation is the actualization of a possible world, where the possible world is understood as one of many options possible in themselves and external to God Himself. That would, again, compromise tawhi $\bar{l} d$, because the possibilities of things would be co-eternal with God. Rather, Abū al-Hudhayl regarded the possibilities of things as residing in God's power (qudra), rather than as external objects of that power.

Combining the two arguments, we can say that God knows that things are possible by knowing His own power. Thus Abu alHudhayl says that in one sense God's knowledge is infinite, because He knows Himself, while in another it is finite, because by knowing Himself He knows the limited world He will create. ${ }^{42}$ This solution was not universally accepted by the Mu'tazila. For instance, Hishām ibn 'Amr al-Fuwațī, another student of Abū alHudhayl's, denied that the non-existent is a thing prior to its creation, but maintained that this did not compromise God's knowledge. ${ }^{43}$ Presumably he did so precisely because he was concerned that possibles would in fact be both eternal and distinct

${ }^{40}$ Al-Khayyāṭ, Kitāb al-Intișār, 16.2-10.

${ }^{41}$ See Frank, "Al-Ma'dūm wal-Mawjūd," p. 190: "al-Shaḥhām was solely concerned with the question of the possible."

${ }^{42}$ Again, see al-Khayyāt, Kitāb al-Intișār, 16.2-10.

${ }^{43}$ Al-Khayyāt, Kitā b al-Intiṣār, 50.3-5: "The dissent of Hishām al-Fuwaṭi on this point is about what to call the objects of knowledge: are they 'things (ashyā'), prior to their generation (kawn), or not? But about whether God is knowing or not, he did not [disagree]." 
from God, if they were $a s h y \bar{a}$ '. Yet the majority view, elaborated in the later tradition, was that the possible or non-existent is indeed a thing, and an object of God's knowledge and power.

Non-being also figures prominently in al-Kindì's treatment of creation. He says that all generation may be defined as "bringing being to be from non-being" (FP 118.18 [RJ 33.25]). Creation is a special case of this: in his compilation of philosophical definitions, he defines $a l-i b d \bar{a}$ ', creation or origination, as "the manifestation (izhār) of the thing (al-shay') from non-being ('an lays)." ${ }^{44}$ A much fuller exposition of the mechanism of creation may be found, rather unexpectedly, in a digression from alKindi's summary of the Aristotelian corpus. ${ }^{45}$ The digression takes the form of an exegesis of a passage from süra 36 of the Qur'ān, and is intended to show the superiority of prophetic knowledge (or at least, the way knowledge is expressed in prophetic texts) over philosophical knowledge. ${ }^{46}$ Richard Walzer has already mentioned this passage in connection with the Mu'tazila, because it shows al-Kindi taking their rationalist approach to interpretation of the Qur'ān. ${ }^{47}$ But here I am interested not so much in the fact that al-Kindi is using an interpretation of the Qur'ān as an opportunity to expound a theory of creation, as I am interested in the theory itself.

In the passage from the Qur'àn quoted by al-Kindī, the unbelievers ask: "who will revivify the bones, when they are decayed?" The response is as follows: "say that He will revivify them Who first brought them forth at one time, and Who knows

${ }^{44} \mathrm{~F} \bar{\imath}$ hudūd al-ashyā' wa rusūmihà (On the Definitions and Descriptions of Things), al-Kindī, Rasā'il al-Kindì al-falsafiyya, 165-179, at 165.11. For this treatise see F. Klein-Franke, "Al-Kindī's 'On Definitions and Descriptions of Things'," Le Muséon: Revue des études orientales, 95 (1982): 191-216; also M. Allard, "L’Épître de Kindī sur les Définitions," Bulletin d'études orientales de l'Institut français de Damas, 25 (1972): 47-83. Less easily available but extremely useful is T. Frank, Al-Kindī's "Book of Definitions": its Place in Arabic Definition Literature (unpublished PhD dissertation, Yale University, 1975), which traces the sources of many of the definitions. In what follows I will refer to the work simply as On Definitions. See below, footnote 87, for the authenticity of this work.

${ }^{45}$ R. fì kammiyyat Kutub Arisțūtālìs wa mà yuhtāju ilayhi fì tahșìl al-falsafa (On the Quantity of the Books of Aristotle and What is Required for the Attainment of Philosophy), al-Kindī, Rasā'il al-Kindī al-falsafiyya, 363-84. An earlier edition, with a translation into Italian, is M. Guidi and R. Walzer, Uno Scritto Introduttivo allo Studio di Aristotele (Rome, 1940).

${ }^{46}$ I take it to be significant that al-Kindī praises Muhammad's statement as being superior to philosophy in its brevity and clarity (373.14), but not necessarily in its content.

${ }^{47}$ Walzer, Greek into Arabic, pp. $177 \mathrm{ff}$. 
all creation. He struck fire from the green trees, and from it you strike fire. Or is He who created the heavens and the earth unable to create their like? Surely, He is the Creator (al-khāliq), the knowing. When He wills something (shay'an), His command is to say to it: 'Be!' and it is" (373.18-374.1, 374.11-12, 375.6-8, and 375.16-17, citing Qur'ān 36.78-82). Al-Kindì's interprets the passage piece by piece. He first points out a flaw in the unbeliever's position:

The questioner, who does not believe in the power of God, the great and exalted, must nevertheless admit that something is (kāna) after not having been (lam yakun), and that his bones formerly were not - they were nonexistent (ma'düm) - but now must necessarily be, after not having been [that is, presumably, because the unbeliever's bones must exist for him to have asked the question in the first place]. (374.6-8)

The relevance of this for the problem debated by the Mu'tazila is clear: we have a thing, in this case the opponent's bones, that was formerly $m a^{\prime} d \bar{u} m$ but is now something that exists. How is this possible?

Al-Kindi takes his cue from the mention of the production of fire from the trees:

For He made fire from not-fire (ja'ala min lā nārin nāran), or heat from notheat. Thus something is necessarily generated from its contrary. For if what comes to be (al-hădith) did not come to be from the substance ('ayn) of its contrary, and if there is no intermediary between the two contraries - by "contrary" I mean "it" and "not-it" (huwa wa lā huwa) - it would have to come to be from itself (min dhätihi). But then its essence $(d h \bar{a} t)$ is always fixed, eternal and without ${ }^{48}$ beginning. For, if dryness does not come from not-fire, then it must come from fire, so that fire will come from fire, and [this] fire from [another] fire, and inevitably there will endlessly (sarmadan) and eternally be fire from fire and fire from fire. Therefore fire would always exist, and there would never be a state ( $h \bar{a} l)$ where it is not (hiya laysun). Thus there would never be fire after there was no fire. But fires do exist (mawjūda) after not being (lam takun), and are destroyed after existing. So the only remaining possibility is that fire is generated from not-fire, and that every generation is from what is other than itself. So everything that is generated is generated from "not-it" (lā huwa). (374.12-375.5)

Al-Kindî's central point is one with a long heritage: all change or generation is from contraries. ${ }^{49}$ Fire, for example, is dry, so it must come from something not-dry. This principle goes back at

${ }^{48}$ Adding $l \bar{a}$ with both editions.

${ }^{49}$ Compare FP 113.13: "Every change is only into its most proximate contrary." 
least as far as Plato's Phaedo (70e-72a), but al-Kindī more likely has in mind the account of change in Aristotle's Physics (I.7-8, cf. Categories 10). He agrees with Aristotle that, whenever something comes to be F, it comes to be from not-F; or, as he says here, huwa comes to be from là huwa.

Yet al-Kindi goes on to apply this principle in a most unAristotelian way, arguing that if something comes to be - not comes to be a certain way, but comes to be simpliciter - then it too must come from a contrary state. That is, it will come to be from a state that is contrary to being. This state is the state of non-being, to which al-Kindī has already referred, using not only 'adam and negations of the verb kāna, but also his characteristic terminology of lays (non-being) as opposed to ays (being). ${ }^{50} \mathrm{He}$ sets out his view as follows:

In their hearts the unbelievers denied the creation of the heavens, because what they believed about the period of time needed for their creation was based on an analogy with the acts of mankind. For, in the case of human acts, the greater the work produced ('amal), the longer is the period [of time] required, so that for [humans] the greatest of sensible things [i.e. the heavens] would take the longest amount of time to produce. So then, [God] said that He, great be His praise, needs no period [of time] to originate. And this is clear, because He made "it" from "not-it" (ja'ala huwa min lā huwa). If His power (qudra) is such that it can produce ( $\mathrm{ya}^{\text {' }} \mathrm{malu}$ ) bodies from not-bodies, and bring being out of non-being (akhraja aysan min laysin), then, since He is able (qädir) to perform a deed with no material substrate (min là ținatin), He does not need to produce $\left(\mathrm{ya}^{\prime} \mathrm{malu}\right)$ in time. For, since there can be no act $\left(f{ }^{\prime} l\right)$ of mankind without a material substrate, the act that does not need to act upon a material substrate has no need of time. "When He wills something, His command is to say to it: 'Be!' and it is." That is, He only wills, and together with His will is generated that which He wills - great be His praise, and exalted His names above the opinions of the unbelievers! (375.9-18)

This passage gathers together numerous points about creation. Several of these points have to do with al-Kindi's famous rejection of the world's eternity, to which I have already alluded in section (I). His claim that the world is made in no time and without a material substrate (tīna) is intended to mark the distinctiveness of creation as opposed to other kinds of change or causation. Creation is contrasted especially to human causation, as al-Kindi makes clear by charging the unbelievers with failing to distinguish divine action from human action.

\footnotetext{
${ }^{50}$ On this terminology see my "Before essence and existence: Al-Kindī's conception of being," The Journal of the History of Philosophy, 40 (2002): 297-312, at p. 300.
} 
These distinctive features of creation - that it requires no material cause and no time - are carefully chosen. In Physics VIII.1, Aristotle had argued for the eternity of the world precisely on the assumption that if the world were generated, the generation of the world (like other changes or motions) would be the actualization of something potential (dunaton), in other words a material substrate (251a10-11). Furthermore, argued Aristotle, as a change or motion this generation will occur in time, so that there will be a moment prior to the change. If there is always a prior moment, then time itself is eternal, which Aristotle takes to show that the world is eternal after all (251b10-18), since time is the measure of motion. Al-Kindì is, then, arguing precisely against Aristotle's conception, on which the generation of the world would be a change like other change.

He is not, however, the first philosopher to reject Aristotle's arguments on this point. It is well known that John Philoponus, the 6th-century Christian commentator, attacked Aristotle in a work now lost except for fragments preserved in Simplicius and a few other sources, some of them Arabic. ${ }^{51}$ It is also well known that al-Kindi drew on this work in his arguments against the eternity of the world in $F P .{ }^{52}$ But it has not, to my knowledge, been noticed before that the passage we have been examining from On the Quantity of the Books of Aristotle is also directly dependent on Philoponus, as the following parallels show:

Al-Kindī, 374.15-374.4: For, if dryness does not come from not-fire, then it must come from fire, so that fire will come from fire, and [this] fire from [another] fire, and inevitably there will endlessly and eternally be fire from fire and fire from fire. Therefore fire would always exist, and there would never be a state where it is not. Thus there would never be fire after there was no fire. But fires do exist after not being, and are destroyed after existing. So the only remaining possibility is that fire is generated from not-fire, and that every generation is from what is other than itself.

Philoponus, fragment 120 [1151.8-16]: Just as this matter has become fire from some prior, underlying fire (proupokeimenou puros), and the latter from yet another [fire], [and just as] it is possible to stop ascending at some point

${ }^{51}$ See Philoponus, Against Aristotle on the Eternity of the World, translated by C. Wildberg (London, 1987). The Greek text is in Simplicius, Commentary on the Physics, edited by H. Diels (Berlin, 1895). Translations from this work are modified versions of those given by Wildberg; I cite by Wildberg's fragment number followed by page and line citations from the Diels edition.

${ }^{52}$ See H.A. Davidson, "John Philoponus as a source of medieval, Islamic and Jewish proofs of creation," Journal of the American Oriental Society, 89 (1969): 357-91. 
at some fire that did not come to be from some other fire when its matter was kindled, but [came to be] due to friction or due to some other cause, but not from fire at any rate, so it is equally not impossible to see the same happening also in the case of the generation of things from one another. Now, whatever is generated by nature is the result of generation of one thing from another, but it is nevertheless possible that they possess a beginning of existence, and that there is some first thing in each kind of case that did not attain generation from some pre-existing (prouparchontos) thing, either similar or dissimilar.

Al-Kindī, 375.13-15: If His power is such that it can produce bodies from notbodies, and bring being out of non-being, then, since He is able to perform a deed with no material substrate, He does not need to produce in time.

Philoponus, fragment 119 [1150.23-25]: If God produces in the same way as nature, He will not be different from nature. [Thus] He has created the matter of bodies out of not-being ( $e k m \bar{e}$ ontōn), for He certainly did not [create them] out of a substrate.

The parallels are not quite precise, as one might expect given that both texts may relate to Philoponus only indirectly: quoted by the hostile Simplicius on the one hand, and on the other transmitted to al-Kindī via an Arabic translation and then presumably paraphrased by al-Kindi for use in this context. But they seem to show something quite remarkable: that al-Kindi was using the work of the Christian Philoponus as part of an interpretation of the Qur'ān. (Fortuitously, Philoponus' example of the production of fire - an example that also appears in Aristotle (251a15-16) in the text Philoponus is attacking - provides al-Kindi with an opportunity to bring Philoponus' remarks directly in contact with the Qur'annic text on God's creation of fire from the trees.) The passages on which al-Kindi draws here come from Book VI of Philoponus' attack on Aristotle, a Book designed expressly to refute Aristotle's argument in Physics VIII.1. This explains why al-Kindi fastens onto the issues of the material substrate and of time: these are the issues raised in Aristotle's discussion and in Philoponus' refutation.

The other purpose of Philoponus' Book VI is to argue for the possibility of creation out of "not-being ( $m \bar{e}$ on)." ${ }^{53}$ Indeed the second of the two Philoponus quotations I have just given is preceded by Philoponus' remark that "if nature creates (dēmiourgei) out of things that are (ontōn), it is not necessary that God does so as well. For if the world did not exist always, clearly God created it out of not-being" (119 [1150.21-23]). This

${ }^{53}$ Fragments 116 [1142.3, 13-16, 21], 119 [1150.23, 25], 131 [1177.25]. 
takes us back to al-Kindi's identical claim that what is created comes from the contrary of being, which is non-being (lays). Despite all the disanalogies between creation and more typical change, creation still obeys the law that all change is a change from one contrary to another. Non-being (the thing that does not yet exist) is thus that out of which God creates.

Although al-Kindi draws on Philoponus to reach this conclusion, the passage is more than a recapitulation of a Greek source. For one thing, the elaboration of the argument from contraries seems to be al-Kindi's own, as it is not based on anything we find in Philoponus. This is central to al-Kindì's argument, and shows him developing a strategy much like that of Philoponus: using Aristotle against himself. For another thing, other features of the argument show that, although al-Kindi has in mind the work of his Greek, Christian ally Philoponus, he is also thinking of the contemporary debate amongst the Mu'tazila. In fact I would argue that he is here giving the same answer as did al-Shaḥām to the question of whether non-being is a thing. $\mathrm{He}$ answers that it is, because non-being must serve as the contrary to which created being is opposed. This was already suggested by the definition we saw al-Kindi give of creation ("the manifestation of the thing from non-being") in On Definitions. ${ }^{54}$ It is confirmed by what al-Kindi goes on to say at the end of the passage we have been studying: that God's command "Be!" is addressed, using the second person, to non-being (idh laysun mukhātabun).

I need to defend my interpretation of this passage, because the meaning of the Arabic is disputed. ${ }^{55}$ The best evidence for my interpretation, apart from the fact that it is suggested by the

\footnotetext{
${ }^{54}$ Here it is not only the term "thing (shay')" that suggests the parallel with the Mu'tazilite position, but the term "manifestation (izhār)." Zahara, "come to light," "appear," has the connotation that what was hidden has been revealed, which might suggest that "the thing" was already something, namely something hidden (in God's power?), before being created.

${ }^{55}$ I follow Abū Rìda in understanding $l-y$-s as a noun (see his footnote 8 on page 375) rather than a verb, and reading mukhătab ("is spoken to") rather than mukhätib ("is speaking"). Jolivet, L'intellect selon Kindi, p. 107 footnote 5, also agrees with this reading. Here one should compare the two published translations of the work, that in Guidi and Walzer, Uno Scritto Introduttivo, and the Spanish translation in R.R. Guerrero and E.T. Poveda, Obras Filosoficas de al-Kindī (Madrid, 1986). Guidi and Walzer render it: "Iddio non rivolge la parola direttamente ad alcuno" (reading mukhāțib, evidently), and Guerrero and Poveda translate: "aquí se interpola a lo que no tiene capacidad de ser interpelado."
} 
context of the argument about non-being as the contrary of being, is that there is a close precedent for the thought I am attributing to al-Kindī. This time the source is not Greek, but Mu'tazilite:

Abū al-Hudhayl said that the creation of a thing, [which is] its being-broughtto-be (takwin) after it was not, is distinct from it [sc. the created thing]. It [sc. the creation] is God's willing it and saying to it, "Be!" [...] God's originating something (al-shay') after it was not is its creation. ${ }^{56}$

Note that Abū al-Hudhayl's claim that God need only will something immediately to create what He wills has also just been asserted by al-Kindi ("He only wills, and together with His will is generated that which He wills," cited above). ${ }^{57} \mathrm{Al}$-Kindi goes on to explain that, while strictly speaking it makes no sense to speak to non-being in the second person, Arabic speakers often "use [expressions] about the thing that do not belong to it by nature" (376.1). As Walzer noted, the appeal to a metaphorical interpretation here is similar to hermeneutic strategies used by the $\mathrm{Mu}^{6}$ tazila. ${ }^{58}$ Thus the end of the digression features numerous points of overlap with the Mu'tazila. For our purposes the most important such point is that non-being, i.e. that which has not yet been created, is the recipient of God's creative act.

My interpretation is also bolstered by what al-Kindī says elsewhere: in a work on the nature of the heavens to be discussed more fully in section (III) below, al-Kindī remarks that, "because [God's] power is bringing ( $i k h r a \bar{j} j$ ) the ma ${ }^{\prime} \bar{a} n \bar{l}$ into existence (kawn), it creates all substances, both simple and composed." ${ }^{59}$ I hesitate to translate the technical term $m a^{6} \bar{a} n \bar{\imath}$ (also found in $\mathrm{Mu}^{6}$ tazilite contexts, but used differently) for fear of prejudging the correct interpretation. Rashed and Jolivet propose "ideas," and Abū Rīda (footnote $7 \mathrm{ad}$ loc) suggests that they are objects of God's knowledge. I believe that al-Kindi uses it to refer to possibilities or potentialities that are actualized by God's creative act. ${ }^{60}$ The

\footnotetext{
${ }^{56}$ Al-Ash'arī, Maqālāt al-islāmiyyīn, 363.10-11, 363.15-364.1 [VE XXI.100].

${ }^{57}$ See further Walzer, Greek into Arabic, p. 183, and Jolivet, L'intellect selon Kindī, p. 110.

${ }^{58}$ Walzer, Greek into Arabic, pp. 182-3, and Guidi and Walzer, Uno Scritto Introduttivo, p. 388.

${ }^{59} \mathrm{Kitāb}$ fì al-ibāna 'an al-'illa al-fā íla al-qarība li-al-kawn wa al-fasād (On the Explanation of the Proximate, Agent Cause of Generation and Corruption), 244-261 [RJ 177-199], at 257.10 [RJ 195.6-7]. Cited by Jolivet, L'intellect selon Kindī, pp. 122-3, also in the context of discussing the relationship between al-Kindi and the Mu'tazila.

60 The basis of my interpretation of this sentence as a reference to the actualization of possibilities is the word $i k h r a \bar{j}$. Al-Kindī uses the verb kharaja as a technical term,
} 
same view might also be inferred from a passage in $F P$ where alKindī characterizes the eternal as follows:

The eternal ( $a l$-azalī) is what must not have been non-existent ${ }^{61}$ in any respect (muțlaqan). For the eternal has nothing existing prior to its being (lā qabla kawniyya li-huwiyyatihi). (113.1-2 [RJ 27.8-9])

This may be compared to his definition of the eternal in $O n$ Definitions: "Eternal (al-azalī)': that which was never was not" (169.10), and the characterizations of creation we have already seen above (the manifestation or bringing-to-be of being from non-being, lays). Something that is not eternal, that is, something that was not, is preceded by non-being. Creation is nothing but the granting of being or existence (variously expressed as kawn, wujūd, huwiyya, ays) to such a thing. His agreement with the $\mathrm{Mu}$ 'tazila on this point is significant, as is the philosophical argument he gives for the point in his interpretation of Qur'ān 36: an interpretation that draws on Greek philosophy to prove a $\mathrm{Mu}$ 'tazilite point of view. ${ }^{62}$

\section{FREEDOM}

Perhaps the most notorious doctrine held by the $\mathrm{Mu}$ 'tazila is their affirmation of human freedom. ${ }^{63}$ Indeed this is treated as something of a litmus test for inclusion in the Mu'tazilite "school." AlAsh'arī says that Dirār ibn 'Amr, who agreed with the Mu'tazila on many points, cannot be counted as $\mathrm{Mu}$ 'tazilite because he diverged from them (färaqa) in holding that human actions are created by God rather than by human agents. ${ }^{64}$ The Mu'tazila believed that human freedom is a necessary condition for divine

meaning "to emerge [into actuality]." See for example al-Kindī, Rasā'il al-Kindī alfalsafiyya , 246.4-5 [RJ 179.14-15], 250.4, 8 [RJ 185.9, 12], 251.13, 17 [RJ 187.11, 14], 268.18. The same verb is used for creation in the passage we studied from $O n$ the Quantity of Aristotle's Books, at p. 375.13.

${ }^{61}$ Following the interpretation of Ivry.

${ }^{62}$ The situation may be more complicated still, given that there is some evidence that the Mu'tazila (especially al-Nażāam) themselves drew on Philoponus' Against Aristotle in their arguments against the eternity of the world. See Davidson, "John Philoponus," pp. 375-6, 379 .

${ }^{63}$ On this see D. Gimaret, Théories de l'acte humain en théologie musulmane (Paris, 1980).

${ }^{64} \mathrm{Al}-\mathrm{Ash}$ 'arī, Maqālāt al-islāmiyyīn, 281.2-5 [VE XV.13]. Al-Khayyāṭ, Kitāa blIntișār, 98.4-5, excludes him from the Mu'tazila in part for the same reason. 
justice ( $a d l$ ). Part of the point here is that God commands good and forbids evil, and will reward the believers and punish wrongdoers. He cannot do any of this justly unless we choose to believe or do wrong freely. ${ }^{65}$ Equally central is the idea that God does not (or even cannot) act unjustly, ${ }^{66}$ and thus cannot be the author or agent of the unjust human action. In addition, the $\mathrm{Mu}$ 'tazila thought it simply obvious that we act freely, that is, that we possess a power to exercise choice (ikhtiyār).

Thus determining what al-Kindī has to say on the subject of human freedom is of paramount importance for understanding his relation to the Mu'tazila. Unfortunately any works al-Kindi devoted specifically to the topic have been lost. ${ }^{67}$ Still, we can reconstruct his position to some extent from what survives. The most direct evidence is to be found in his work On Definitions. Early in the work, al-Kindi provides us with the following definition:

"Choice (al-ikhtiyār)": volition (irāda) preceded by deliberation (rawiyya) together with discrimination (tamyiz) (167.1).

Two of the terms used in this definition of choice are themselves defined shortly thereafter:

"Deliberation (rawiyya)": wavering (imāla) between inclinations ${ }^{68}$ in the soul (168.1).

"Volition (irāda)": a power (quwwa) by which one intends (yaqșidu) one thing rather than another (168.7).

These definitions suggest that al-Kindī believes that humans have a power of free choice. The possibility that such a power belongs only to God is in fact already diminished by the idea that choice

${ }^{65}$ See the discussion of this argument in Gimaret, Théories de l'acte humain, pp. 252ff. Sometimes the argument is made without reference to divine justice: it is simply incoherent to imagine a command being given to an agent who cannot freely follow the command. See below for al-Kindì's acceptance of this claim.

${ }^{66}$ On the debate whether God can act unjustly, even though He does not, see for example the report of al-Nazzām's view at al-Khayyāt, Kitāb al-Intișār, sections 24-25.

${ }^{67}$ See above, footnote 11 .

${ }^{68}$ Reading khawātir, with Klein-Franke, "Al-Kindī's 'On Definitions and Descriptions of Things'," p. 211 (number 22), and Frank, Al-Kindì's "Book of Definitions", p. 81. See just below for al-Kindī's definition of $k h a \overline{a t i r}$, which is a second stage after conceiving a "thought (sānih)." The contrast seems to be between an idle thought and an actual tendency towards doing something. For instance, one sees an apple, and becomes aware that one could eat the apple, which is a "thought." Only then does one form the further "inclination" actually to eat the apple. Then one "deliberates" about whether to follow this inclination, or a rival inclination not to eat the apple. 
involves rawiyya, or deliberation, which according to other Kindī circle texts plays no part in divine action. ${ }^{69}$ In any case the freedom of created beings is explicitly embraced by al-Kindī later on in the text:

"Volition of the creature (irādat al-makhlūq)": the faculty of the soul (quwwa nafsāniyya) that goes towards an action due to a thought (sāniḩ) (175.13-14).

Clearly it is imperative for us to understand this last definition, since it so clearly asserts the reality of human volition. We can begin by noting that it is the culmination of a series of definitions that establish a causal sequence in the process of human will. First the agent has a "thought (sānih)," which gives rise to an "inclination (khätir)" (175.7). The decision causes a "will" or "volition" (irāda) (175.8). Irāda is in turn the cause of isti "māl, which given the context would seem to mean "action." 70 It will be worthwhile to look more closely at the definition of isti ' $m \bar{a} l$ :

Its cause is the volition. It may also be the cause for further inclinations (khātarāt). So there is a causal circle (dawr) that attends on all of these causes, [which] are the act of the Creator ( $f i^{\prime} l a l$ l-bäri'). Therefore we say that the Creator, may He be exalted, makes some of His creatures be thoughts (sawänih) for others, makes some to be actualized (mustakhraja) ${ }^{71}$ by others, and makes some to be moved by others (175.9-12).

What is most striking about this passage is the suggestion that our actions are part of a cyclical causal process (dawr), which I take to mean that after thoughts and inclinations cause volitions that cause actions, these actions then cause further thoughts and inclinations, and the process is repeated. All the stages in the cycle, furthermore, are said to be caused by God. Thus it would seem that our actions are in fact determined in two ways. First, they are part of a causally determined sequence or cycle. Most immediately they are caused by thoughts and inclinations, and these are not obviously under our causal control. ${ }^{72}$ Second, the

${ }^{69}$ See especially the Theology of Aristotle, edited as Plotinus apud Arabes by 'A. Badawì (Cairo, 1955), at pp. 67.4, 119.12, 140.9.

${ }^{70}$ The use of this term may correspond to khrēsis in his Greek source, if Frank, AlKindī's "Book of Definitions", p. 58, is right in seeing John of Damascus as that source.

${ }^{71}$ See above, footnote 60.

${ }^{72}$ Perhaps al-Kindi means that my own choices eventually lead to my own decisions, which then cause further choices: a circular explanation, but is it deterministic? Presumably our thoughts and inclinations are frequently caused by an external factor: my thought that I might eat an apple is occasioned by seeing an apple, the thought causes an inclination to eat it, which causes the volition to eat it. One might think that my volition will be undetermined as long as my decision stems from a prior volition of 
whole network of causes of which our actions form a part is itself caused by God. The upshot is that al-Kindi is accepting both of the sorts of causal determinism that might compromise human freedom: our actions are determined both by events in the created world and by divine agency. ${ }^{73}$

If this is right, then how can al-Kindi nevertheless affirm that we have a power of volition and choice? I believe that he is taking a position that is now known as compatibilism: the view that human actions can be both free and determined. There was certainly precedent for compatibilism in the Greek tradition, especially in the Stoics, whose view could have been known to al-Kindi through Peripatetic criticisms if through no other route (though I think it is doubtful that there was significant Stoic influence on al-Kindī). Admittedly, the evidence adduced thus far for this interpretation is slight, but I will now try to show that other surviving passages where al-Kindi mentions freedom can best be understood if we hold that he was, indeed, a compatibilist.

First it should be briefly noted that statements by two of alKindì's students lend some support to this hypothesis. His disciple al-Sharakhsi affirms both the reality of human freedom and its link to "discernment": "discerning actions occur through the volition of the one who chooses (al-af'älu al-tamyizziyyatu

my own (e.g. my prior resolution to eat more apples), but of course this is only the case if that volition itself was undetermined. What is needed to avoid determinism is the claim that sometimes volitions happen without being caused at all, but al-Kindi seems to deny precisely that in his definitions. I here speak of determinism as including the claim that causes necessitate their effects, since al-Kindi seems to conceive of causes in this way, as will become clear in the cosmological context explored below. This should not be taken to imply that al-Kindì is a logical determinist, however: I believe he would accept that unactualized actions are logically only possible, though it is causally necessitated that an alternative action is chosen. On this see the discussion of modality in the final section of my "Abū Ma'shar, al-Kindī and the philosophical defense of astrology," Recherches de philosophie et théologie médiévale, 69 (2002): 245-70.

${ }^{73}$ Frank, Al-Kindī's "Book of Definitions", claims that al-Kindì's definitions on this topic are based ultimately on the Expositio fidei of John of Damascus (whereas KleinFranke, "Al-Kindi'’s 'On Definitions and Descriptions of Things'," p. 202, compares the first definition of ikhtiyār to a passage in Andronicus of Rhodes). I cannot assess this claim here, and will say only that Frank seems right at least in finding a structural similarity between the two accounts. At any rate the following both seem to be the case: (a) the various definitions on human action and freedom are derived from Greek sources, yet (b) the crucial section of the definition of isti 'māl, beginning in the second sentence of my translation, is al-Kindi's own addition rather than a recapitulation of his Greek source (Frank, Al-Kindi's "Book of Definitions”, p. 138, says that the definition is "greatly expanded" from what can be found in John of Damascus). 
wāqi 'atun bi-irādati al-mukhtāri)." ${ }^{74}$ And the reknowned astrologer Abū Ma'shar, who according to the Fihrist took up philosophy thanks to al-Kindì, does not just say that humans are free; he does so with an argument that I have elsewhere argued is compatibilist. ${ }^{75}$ His position is set out in the first book of the Mudkhal al-kabìr 'ilā 'ilm ahkām al-nujūm (Great Introduction to the Science of Astrology). ${ }^{76}$ It appears as the response to an objection, that if astrology is capable of predicting human actions, then those actions must be predetermined and not free. Abū Ma'shar admits the antecedent of this argument:

Just as the stars indicate the possibility and choice that belong to a man, so they indicate that a man will only choose what the stars indicate, because his choice of a thing or its opposite will be by the rational soul whose mixture with the animal soul in individuals is determined by the indications of the stars. (I.860-2, my emphasis)

But he nonetheless insists that we are free, and indeed that our capacity for choice (ikhtiyār) is what distinguishes us from the other animals (see I.739-40).

The best evidence for al-Kindi's compatibilism also comes from the realm of astrology and cosmology. In his treatise explaining why the Qur'ān claims that the heavens "bow down" and are obedient before God, al-Kindī says the following:

The meaning of "obedience" is "execution of the order of a commander." Now, execution of the order of a commander is only by choice (ikhtiyār), and choice belongs to complete souls, that is, rational [souls]. Therefore the stars... are endowed with obedience. ${ }^{77}$

Before remarking on the philosophical significance of this, let me point out two features of the passage that suggest parallels with the $\mathrm{Mu}$ 'tazila. First, as we saw above, the $\mathrm{Mu}$ 'tazila often argued that if God commands His creatures to do a thing, then this presupposes freedom on the part of the creatures. ${ }^{78}$ Second, the

${ }^{74}$ F. Rosenthal, Ahmad b. aț-Ṭayib as-Sharakhsī (New Haven, 1943), p. 134; cited at Frank, Al-Kindī's "Book of Definitions", p. 59.

${ }^{75}$ See my "Abū Ma'shar, al-Kindī and the philosophical defense of astrology."

${ }^{76}$ Abū Ma'shar al-Balkhī, Liber introductorii maioris ad scientiam judicorum astrorum, edited by R. Lemay (Naples, 1995-6). I have been greatly helped by Charles Burnett's forthcoming English translation.

${ }^{77}$ Risāla fì al-ibāna 'an sujūd al-jirm al-aqșā (On the Explanation of the Bowing of the Outermost Body), in al-Kindī, Rasā'il al-Kindì al-falsafiyya, 244-261 [RJ 176-199], at 246.7-247.13 [RJ 179.17-23].

${ }^{78}$ For Abū al-Hudhayl's definition of obedience as acting in accordance with a divine command (amr), see al-Khayyāt, Kitā b al-Intiṣār, 58.23-59.1. 
ability to choose further presupposes that what obeys has a soul. This claim can be found in the Mu'tazilite author al-Nāshi': "the freely chosen act ( $a l-f i$ 'l al-ihktiyārì) can come only from the soul of the agent." 79 These reminiscences, and the entire context of the treatise as a philosophical account of a Qur'ānic verse, suggest that al-Kindi is again in dialogue with or at least conscious of the $\mathrm{Mu}$ 'tazila as he explains the freedom exercised by the heavenly bodies.

In what does this freedom consist? In On Definitions, we saw that a choice (ikhtiyār) requires not only that one form a volition, but that it be formed in the right way, that is, on the basis of a process of deliberation and discernment (tamyiz). In the case of heavenly motion, al-Kindi once again links free choice to discernment: the heavenly body "is alive and discerning (mumayyiz), so it is clear that its obedience is due to choice (ikhtiyāriyya)" (246.10 [RJ 181.1011]). The capacity for ikhtiyār on the part of the heavens does not seem to require that the heavens could do otherwise than to move in accordance with God's command. Indeed it is most unlikely that al-Kindi would accept this as a possibility, given that, as we will see shortly, the heavens' motion is the instrument of God's providence, which ought not to obtain only contingently. Their freedom seems rather to consist in the fact that they obey God rationally. That is, they perceive the reasons why it is necessary for them to move; it is this that al-Kindi means by the term tamyizz.

The ramifications of this for human freedom become clear in al-Kindi's work On the Explanation of the Proximate, Agent Cause of Generation and Corruption. ${ }^{80}$ In this treatise, which is intended to establish the philosophical basis for the science of astrology, al-Kindi explains that the stars bring about all generation and corruption in the sublunar world by affecting heat, cold, dryness and moisture in the elements and compounds of the elements. It is through this influence that God's providence is exercised:

\footnotetext{
${ }^{79}$ J. van Ess, Frühe mu'tazilitische Häresiographie (Beirut, 1971), 96.14-15 of the Arabic edition. Al-Nāshi' was slightly later than al-Kindī.

${ }^{80}$ See above, footnote 59. The relevance of al-Kindi's astrological works for his views on freedom is noted in T.-A. Druart, "Al-Kindī's ethics," Review of Metaphysics, 47 (1993): 329-57, at pp. 344-7. She adds a passage from al-Kindi's On the Art of Dispelling Sorrows that helps confirm his basic acceptance of human freedom. F. Jadaane, in his L'influence du stoïcisme sur la pensée musulmane (Beirut, 1968), p. 200, claims that for al-Kindì human acts are unfree because of the stars' influence. He detects Stoic influence in al-Kindī, not only in Proximate, Agent Cause but also in his ethical works; Jadaane does not, however, raise the question of whether al-Kindī was a compatibilist like the Stoics.
} 
It has been made clear that the celestial bodies' being in the place where they are... is the proximate agent cause of generation and corruption in generated and corrupted things. That is, by the volition $(i r a \bar{d} d a)$ of their Creator they give rise to this order (tartì $b$ ), which is the reason (sabab) for generation and corruption. [It has also been made clear] that this is from the rule (tadbir) of a wise, knowing, powerful, generous knower who perfects what He makes, and that this rule is perfect in the extreme. For He necessitates the best command, as has been made clear. (236.13-237.1)

Now, if al-Kindī were committed both to human freedom and to incompatibilism, then he would have to insist that human actions are immune to this sort of causal determination from the stars. Instead, like Abū Ma'shar, he is happy to explain our general moral character and our individual volitions as the results of heavenly motion:

It is manifest that in the rotation [of the heavenly body] according to its orbit, it apportions heat, cold, moisture and dryness [in] the bodies below it at all times. [This leads] to the reception of the various kinds of characters of the soul, and to the soul's habits and its volitions (irāda $\bar{t}$ ), in accordance with both the more general mixtures that occur from [the celestial bodies], and the more particular mixture of every one of the generated and corrupted things that are under [the celestial bodies]. For this reason there occur intentions (himam) distinct from initial intentions, and volitions distinct from initial volitions, and this alters form (shakl) and practices. (236.1-5)

Admittedly, al-Kindī does not here explicitly claim that all human actions and choices are brought about by the stars. Given further evidence to be adduced shortly, I am convinced he does think this, but it is not required for my argument. All that is required is that he is willing to admit the compatibility of human freedom with determinism, in this case the physical determinism that results from the mixture of elements and contraries in our bodies. Given that al-Kindī never makes any attempt to define irāda or ikhtiyār in a way that requires the absence of an external cause, it seems justified to say that he consistently takes a compatibilist line.

In this al-Kindì is definitely at odds with the $\mathrm{Mu}^{\text {'tazila, who }}$ were equally consistent in defending an incompatibilist position. This has been shown quite well in the case of the later Mu'tazilite 'Abd al-Jabbār, whose discussion of the psychology of human action has been expertly analyzed by Richard Frank. ${ }^{81}$ 'Abd alJabbār considers the possibility of a position like the one taken

${ }^{81}$ R.M. Frank, "The autonomy of the human agent in 'Abd al-Jabbār," Le Muséon, 95 (1982): 323-55. 
by al-Kindi in the case of the stars' obedience: that an agent's action flows from a rational belief or motivation. He emphatically rejects this account, insisting that a free action can never be predetermined, even by the agent's own belief set and motivations. Of course 'Abd al-Jabbār is later than al-Kindī, but I believe that he is simply making more explicit the incompatibilism that was always assumed in the $\mathrm{Mu}$ 'tazilite tradition. For example, Bishr ibn al-Mu'tamir distinguishes explicitly between acts that are necessitated and acts that are the result of free choice. ${ }^{82} \mathrm{Al}$ Khayyāt gives a particularly clear expression of the $\mathrm{Mu}^{\text {'tazilite }}$ position in expounding the view of Abū al-Hudhayl: "an agent does not perform an act without a similar act being possible for him." ${ }^{83}$ And the Mu'tazilite al-Jāhiz, a contemporary of al-Kindī's, distinguishes between the freedom of ' $a q l$ (intellect) and the necessitation of $\operatorname{tabi}^{\prime} a$ (nature) in human action. ${ }^{84}$

Thus al-Kindi disagrees with the Mu'tazila: they believe that a plurality of acts must be available to an agent in order for the agent to be free with regard to any of those acts, whereas al-Kindi thinks one can freely perform even an act that is necessitated. But in the context of the larger debate, al-Kindi is of course on the side of the $\mathrm{Mu}$ 'tazila, since he does affirm that humans are free (albeit in a sense the $\mathrm{Mu}$ 'tazila would not recognize). A small piece of evidence that al-Kindi's thinking about agency and freedom is related to $\mathrm{Mu}$ 'tazilite discussions is that, in Proximate Agent Cause, he seems to allude to mutawallidàt, "engendered acts":

The agent cause is either proximate or remote. The remote agent cause is like one who shoots an arrow at an animal, and slays it. The shooter of the arrow is the remote cause of the slaying, and the arrow is the proximate cause of the

${ }^{82}$ Al-Ash'arī, Maqālāt al-islāmiyyīn, 393.9 [VE XVII.22]; the view is ascribed to Bishr at line 12 .

${ }^{83}$ Al-Khayyāt, Kitāb al-Intișār, 20.6-7. A useful contrast is provided by the thought of Dirār ibn "Amr, who is often said to have anticipated the Ash'arite doctrine of "acquisition (kasb)," holding that human acts are created directly by God, though they are preceded temporally by "ability (istița $\left.\bar{a}^{\prime} a\right)$ " on the part of the human. See van Ess, "Dirār b. 'Amr und die 'Cahmiyya'," pp. 270ff., and passages translated as VE XV.1215. The incompatibilism of the Mu'tazila is displayed in their attacks on what they saw as the determinism of Dirār.

${ }^{84}$ Like some present-day incompatibilists, Jāhiz admits that free action is only possible when all the motivations and inclinations due to nature are balanced in their mutual opposition (see VE XXX.6, 13; note that he speaks of "inclinations (khawätir)" as an impediment to free action, whereas al-Kindī makes inclination a precursor of choice in On Definitions). 
slaying. For the shooter propels the arrow, with the intent of slaying, while the arrow causes the slaying of the living thing. (219.2-5)

Al-Kindi does not enter here into the $\mathrm{Mu}$ 'tazilite debate about engendered acts: if A causes B and B causes $C$, then is A or B the cause of C? ${ }^{85}$ To take al-Kindi's example, is it the archer or the arrow that is the "agent ( $\left.f \bar{a}^{\prime} i l\right)$," in other words the efficient cause, of the mortal wound of the quarry?

Fortunately, al-Kindi's solution to the problem can be reconstructed from another text. As we saw, his short treatise $O n$ the True Agent asserts that only God is an agent in the proper sense that He acts without His act being caused by a prior agent (see section (I) above). We can understand this more fully by returning to al-Kindī's claim that created things are agents in only a metaphorical sense. What al-Kindi says about the created thing is not that it is both acting and acted-upon, but that strictly speaking it does not act at all: it is "purely an effect" (munfa i $i l$ mahd (). ${ }^{86}$ This is not to say, though, that the created thing cannot cause something else: it can, and is indeed called "the proximate cause" of its effects. Al-Kindi is not an occasionalist. What he means by saying that the created "agent" does not truly act is rather that it does not initiate an act that causes something else. Rather, it gives rise to its effect only as a result of its being acted upon (183.9-14 [RJ 169.14-171.4]). In this sense all acts in the created world are "engendered," that is, they proceed inevitably from the originating first act of God, which is the act of creation, the bestowal of being (183.1-2 [RJ169.7]).

However, taking into account al-Kindì's compatibilism, we can see that this does not prevent created, "metaphorical" agents from exercising freedom. Indeed for him the problem of engendered acts is no longer pressing, and can be solved merely by observing that an act may have many causes, some more "proximate" to the act than others. These causes may "act" because they are necessitated so to act, but only some of these socalled "agents" (in this case, the archer, but not the arrow) exercise a capacity of choice and are, presumably, morally responsible for the result. What is it for such a cause to be free,

\footnotetext{
${ }^{85}$ Particularly prominent is Mu'ammar's treatment of the problem. See the discussion at Daiber, Das theologisch-philosophische System des Mu'ammar, pp. 367 ff.

${ }^{86} \mathrm{My}$ thanks to an anonymous referee at this journal for bringing this point to my attention.
} 
if it is not that the cause initiate its act without external necessitation? To judge from On Definitions, we are free (in other words, we have a power of volition and choice) because of the structure of human psychology: we may be necessitated to choose, but that choice proceeds through a process of rational deliberation, just as in the case of the motion of the heavens, as we saw above. It is this that guarantees human freedom, just as for many modern-day compatibilists. By contrast, on the $\mathrm{Mu}$ 'tazilite, incompatibilist theory, the only freedom (the only power to choose) in any causal chain belongs to the cause that initiates the chain, and whose action is thus uncaused. Al-Kindì's restriction of the term "agent" in its proper sense to such an uncaused cause may be borrowed from this $\mathrm{Mu}$ 'tazilite attitude, with the significant difference that for al-Kindi only God is an agent in this

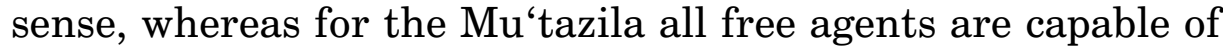
uncaused action. If al-Kindì were an incompatibilist, he could never speak of irāda and ikhtiyār in the case of created things given the position he takes in On the True Agent. The interpretation of al-Kindi as a compatibilist is the only one that allows us to ascribe to him a consistent view. ${ }^{87}$

$$
\text { * * * * }
$$

${ }^{87}$ Here I should address two possible objections to my interpretation: (1) there is no reason to think that al-Kindi is in fact consistent across his corpus, because he was simply drawing on Greek sources and these may have been inconsistent with one another; and (2) I have depended heavily on On Definitions, which may not be authentic. In response to (1) I may refer the reader to my discussion of this problem in The Arabic Plotinus, Appendix section 1. Briefly, I hold that al-Kindi was for the most part trying to be consistent and was not slavishly dependent on his sources. All else being equal, interpretations that show him to have achieved consistency are likely to be historically correct as well as philosophically satisfactory. Regarding (2), the authenticity of On Definitions, this has been thrown into doubt by D. Gimaret in his introduction to the text and translation of the work in Al-Kindī, Cinq Épitres (Paris, 1976), pp. 8-13. After producing some indications of inauthenticity, such as the fact that it is not mentioned in later lists of the Kindian corpus like the one in the Fihrist, Gimaret concludes that its authenticity "n'est rien moins que certaine." I believe on the contrary that the work is almost certainly authentic, though we cannot rule out that some definitions were inserted by later authors. This is suggested by numerous parallels between On Definitions and the rest of the Kindian corpus. Some of these parallels are mentioned by Gimaret. Here I would add only that the distinctive inclusion of "nature" in the Plotinian hierarchy (to yield "First Cause, Intellect, Soul, Nature") represented in the first four definitions is paralleled not only in the Prologue to the Theology of Aristotle, which I believe to have been written by al-Kindi, but also in his Sayings of Socrates (Alfāz Suqrāt) edited by M. Fakhry, "Al-Kindī wa 'l-Suqrāt," alAbhàth, 16 (1936): 23-34, at p. 30.18-19. (On the Plotinian origin of this sequence in On Definitions, see Klein-Franke, "Al-Kindī's 'On Definitions and Descriptions of Things'," p. 199.) What are we to make of the unusual features of the transmission of On Definitions, namely its absence from the Arabic bibliographies and its lack of an 
While one could extend this investigation to deal with other issues, the foregoing makes possible some general conclusions. The previous consensus, especially since Ivry's discussion of the problem, has been that al-Kindi agreed with the $\mathrm{Mu}$ 'tazila on some points but saw them as intellectual rivals more than as allies. Though this seems to me right, it is also worth emphasizing that al-Kindi saw Mu'tazilite discussions as an opportunity: by drawing on the resources of the Greek philosophical tradition, he hoped to solve some of the vexed theological controversies of his time. He was not a mutakallim, but he wanted to respond to his contemporaries and show the relevance of Greek thought to their concerns. In terms of winning over the mutakallimūn this project was a failure, and it is easy to see why. Especially from the standpoint of the later polemics of the kaläm tradition, al-Kindi's positions on problems like divine attributes and human freedom could easily seem to betray, rather than support, $\mathrm{Mu}$ 'tazilite views. The Zāhirite Ibn Hazm would later take al-Kindī to task for falling into self-contradiction, by espousing negative theology and yet describing God as a "cause ("illa)." 88 This accusation is more intelligible in light of the positive theory of attributes we uncovered in section (I). Similarly, al-Kindi is willing to speak of irāda and ikhtiyār belonging to created things, but he denies that humans can initiate (or, to use the terms of the later debate, "create") their acts. Here one should bear in mind that the later controversy was not typically fought over the notion of "freedom," but over whether God or humans have the "power" to produce an act. On this question, al-Kindi is not obviously on the side of the $\mathrm{Mu}$ 'tazila. In fact, the Ash'arites would later reproduce alKindī's claim that only God is an "agent $(f \bar{a} ' i l)$ ". ${ }^{89}$ This illustrates

introductory section addressed to al-Kindi's sponsor? (Both are mentioned by Gimaret, though he is incorrect to say that all other epistles by al-Kindi have been transmitted with these adulatory introductions: for example, neither On the True Agent nor the aforementioned Sayings of Socrates have them). A possible explanation is that $O n$ Definitions was not a formal epistle or treatise by al-Kindi but was intended as a tool to be used in constructing those epistles, and also for consultation by his translators or students. At any rate I think we may include On Definitions in the Kindian corpus: it contains much that al-Kindi repeats elsewhere and nothing he could not have written. It should certainly be used with caution if it is the sole evidence for al-Kindî's view on a particular topic, but in this case my interpretation also draws on al-Kindi's cosmological works.

${ }^{88}$ See Daiber, "Die Kritik des Ibn Ḥazm an Kindīs Metaphysik,” pp. 286-7.

${ }^{89}$ See R.M. Frank, Creation and the Cosmic System: al-Ghazālì \& Avicenna (Heidelberg, 1992), p. 22. 
how un-Mu'tazilite al-Kindī could be when defending a broadly $\mathrm{Mu}$ 'tazilite doctrine. And that in turn helps to explain why, whatever his intentions, al-Kindī's considerable historical influence was almost wholly on the tradition of falsa fa. ${ }^{90}$

${ }^{90}$ I am grateful to Frank Griffel, and to two anonymous referees at this journal, for helpful comments and suggestions. I also received helpful responses from participants at an Arabic philosophy conference in June 2002, and a meeting of the School of 'Abbāsid Studies in July 2002, both held at Cambridge University - especially I would like to thank Ahmad Hasnawi, Wolfhart Heinrichs, James Montgomery, Marwan Rashed, Tony Street, and Josef van Ess. Finally I am very grateful to Sophia Vasalou for helping me revise the final version. Any remaining shortcomings are of course my own. 